Volume 6 Nomor 2, Agustus 2021, halaman 154 - 174.

\title{
Development Of Test Instruments To Measure High Order Thinking Skill (Hots) Mathematics Of Students In MTs 2 States Of Medan City
}

\section{Pengembangan Instrumen Tes Untuk Mengukur High Order Thinking Skill (HOTS) Matematis Siswa Mtsn 2 Kota Medan}

\author{
Qania Agustika Siagian ${ }^{1}$, Prihatin Ningsih Sagala ${ }^{2}$ \\ ${ }^{1}$ Department of Mathematics Education, Universitas Negeri Medan, qaniaagustika@gmail.com \\ ${ }^{2}$ Department of Mathematics Education, Universitas Negeri Medan, alfathmommy81@gmail.com
}

\begin{abstract}
ABSTRAK
Upaya yang dapat dilakukan agar siswa Indonesia mampu ikut bersaing dengan negara-negara lain dalam penilaian TIMSS dan PISA, seharusnya siswa Indonesia harus dibiasakan bertemu dengan instrumen tes yang menuntut High Order Thinking Skill (HOTS). Tujuan pada penelitian ini adalah untuk mengetahui kemampuan berpikir tingkat tinggi matematis siswa, serta mengetahui validitas, reliabilitas, tingkat kesukaran dan daya beda produk instrumen tes berorientasi High Order Thinking Skill (HOTS). Penelitian pengembangan ini menggunakan tipe ADDIE. Ada 57 siswa yang dijadikan subjek pada penelitian ini. Hasil penelitian menunjukkan bahwa 15 soal yang telah dianggap berhasil valid dikembangkan, hal ini pada skor rata-rata penilaian instrumen tes oleh ahli sebesar $91 \%$ dan validitas setiap butir tes dinyatakan "valid" karena $t_{\text {hitung }} \geq \mathrm{t}_{\text {tabel. }}$. Reliabilitas instrumen tes setiap paket soal dinilai reliabel dalam kategori tinggi. Dalam analisis tingkat kesulitan, terlihat bahwa menunjukkan hasil pada kategori mudah dan sedang. Dalam analisis daya pembeda, terlihat bahwa menunjukkan hasil cukup baik dan baik. Hasil rata-rata kemampuan berpikir tingkat tinggi matematis siswa kategori cukup.
\end{abstract}

Kata Kunci : Instrumen Tes, High Order Thinking Skill, ADDIE..

\begin{abstract}
Efforts can be made so that Indonesian students can compete with other countries in the TIMSS and PISA assessments, Indonesian students should be accustomed to meeting test instruments that demand High Order Thinking Skills (HOTS). The purpose of this study was to determine the students' high-order mathematical thinking skills, as well as to determine the validity, reliability, difficulty level, and differentiating power of the High Order Thinking Skill (HOTS) oriented test instrument. This developmental research uses the ADDIE type.. There were 57 students who were used as subjects in this study. The results showed that 15 questions that were considered successful and valid were developed, this is the average score of the test instrument assessment by experts of $91 \%$ and the validity of each test item is declared "valid" because $t_{\text {count }} \geq t_{\text {table. }}$. The reliability of the test instrument for each package of questions was rated as reliable in the high category. In the analysis of the level of difficulty, it appears that the results are in the easy and medium categories. In the analysis of discriminatory power, it appears that the results are quite good and good. The average results of students' high-order mathematical thinking skills are insufficient category.

Keyword(s): Test Instruments, High Order Thinking Skill, ADDIE..

How to Cite: Siagian, Q. A., \& Sagala, P.N. (2021). Development Of Test Instruments To Measure High Order Thinking Skill (Hots) Mathematics Of Students In MTs 2 States Of Medan City. Mathline: Jurnal Matematika dan Pendidikan Matematika, Vol. 6 No. 2, 154 - 174.
\end{abstract}

DOI: https://doi.org/10.31943/mathline.v6i2.222 


\section{PRELIMINARY}

The results of Trends In Mathematics and Science Study (TIMSS) 2015 in Khodaria et al (2019, p.66) Indonesia was ranked 44th out of 49 countries in the world with a math score of 397 with an average of 505. Likewise, the results of the 2018 Program for International Student Assessment (PISA) study showed that Indonesian students were ranked 73 out of 78 countries in the world with a math score of 379 with an average of 489 points (OECD, 2019). Even though the demands of competition in the field of education are very much needed by the younger generation in this era of globalization. Indonesian education must be able to prepare graduates who are able to compete in the world.

Furthermore, other evidence that the higher-order mathematical thinking ability of Indonesian students is still in the low category as the results of Hadi's research (2018) shows that there are $8.33 \%$ of students find it difficult to translate problems, $15.59 \%$ of students find it difficult to transform problems, $32.53 \%$ of students difficulty in the process of working on questions, and $1.34 \%$ of students have difficulty in concluding. The results of Ardhana's research (2017, p.16) concluded that the percentage in the category of high order thinking skills which includes analyzing (C4), evaluating (C5), and creating (C6) only reached $2.941 \%$, which is still low.

To reach students from Indonesia who are able to compete with students from other countries, it is necessary to improve the quality of education, which can be built by improving the quality of learning and the quality of the assessment system (Malik, 2018, p.14). The quality of this good learning can be seen from the results of the assessment. Therefore, teachers need to plan lessons, strategies, and question-based constructs that help students think at a higher level, think creatively and think critically. In connection with the structure of the question, the assessment of learning outcomes must be carried out properly, starting from the determination of the instrument, preparation of the instrument, review of the instrument, implementation of the assessment, analysis of the assessment results, and the follow-up program of the assessment results. Efforts can be made so that Indonesian students can compete with other countries in the TIMSS and PISA tests, Indonesian students must get used to meeting questions that are in accordance with the TIMSS and PISA assessment standards. Referring to the $21^{\text {st }}$-century learning framework, HOTS is the answer in responding to the challenges of $21^{\text {st }}$-century learning (Rapih \& Sutaryadi, 2018, p.77).

The results of observations made by researchers on students at MTs Negeri 2 Medan make the evidence stronger that students' higher-order mathematical thinking skills 
are still low. The questions made by the teacher are known to not require all higher-order mathematical thinking skills. Questions made by the teacher can only demand to analyze information from what is known and what is asked from the question.

Anderson \& Krathwohl (2001) dalam Motlhabane (2017, p.922) classify cognitive processes into six categories, namely remembering, understanding, applying, analyzing, evaluating, and creating. This is in line with the opinion of Arlianty et al (2018, p.1) based on Bloom's Taxonomy, the categories of remembering, understanding, applying are Lower Order Thinking Skills (LOTS) while analyzing, evaluating, and creating are High Order Thinking Skills (HOTS).

According to Heong et al (2011) in Kusuma (2017, p.26) this higher order thinking ability requires someone to apply information to reach possible answers in new situations. The HOTS assessment instrument as a learning assessment is effective for training students' HOTS and effective in measuring students' thinking skills based on each student's HOTS level. A good test must meet the following criteria well.

1. Validity

Validity is a term related to the extent to which a test has measured what it is supposed to measure. Validity is the ability of a measuring instrument to accurately measure the condition being measured. As Nieveen \& Piomp (2007) in Hajar et al (2021, p.4) stated in An Introduction to Educational Design Research, the component of material should be based on the state-of-the-art knowledge (content validity) and all components should be consistently linked to each other (construct validity). In this research, the product produced is a high-level mathematical thinking test instrument. To determine the quality of the developed product, it must have validity criteria. To be able to achieve the validity of the test instrument through an expert validation process. The indicator components of the expert validation aspect in general are based on language, construct, and content.

\section{Reliability}

The concept of reliability or often called reliability (reliable or trustworthy) refers to consistency or homogeneity. This consistency and homogeneity can be seen from the score of the measurement results, both once and several times (Febri E., 2017, p.139).

\section{Level of Item Difficulty}

The level of difficulty of the item means the degree of a question. Good quality questions are not too difficult and not too easy in other words the questions are proportional (Arifin, 2017, p.266). 


\section{Differentiating Power of Questions}

The calculation of discriminating power is a measurement of the extent to which an item can distinguish between students who have mastered competence and students who have not/less mastered competence based on certain criteria (Arifin, 2017, p.273).

According to Krathwohl (2001) indicators for measuring higher-order thinking include analyzing, evaluating, and creating (Febiana 2019, p.10), which are described below:

(1) Analyzing

1a. Analyze incoming information and break down or structure the information into more specific parts to find out patterns/formulas or relationships.

1b. Able to recognize and distinguish causal factors and distinguish between causal factors and influencing factors from complex schemes.

1c. Identify/formulate the question.

(2) Evaluate

2a. Assess solutions, ideas, and methodologies using appropriate criteria or existing standards to determine their effectiveness or usefulness.

2b. Generate hypotheses, critique, and test them.

2c. Accept or reject a question based on predetermined criteria.

(3) Creating

3a. Generalize an idea or perspective about something.

3b. Designing a solution to solve a problem.

3c. Organize elements or parts into a new structure that has never existed before.

From the existing problems and the provisions for developing a test instrument that can measure students' High Order Thinking Skills (HOTS), this study aims to:

1. Knowing the high-order mathematical thinking skills of class VIII MTs Negeri 2 Medan on the subject matter of Number Patterns, Sequences, and Series.

2. Knowing the validity, reliability, level of difficulty, and differentiating power of the test instrument product-oriented to High Order Thinking Skill (HOTS) on the material of Number Patterns, Sequences, and Series in class VIII SMP/MTs.

\section{METHOD}

This research was conducted at MTs 2 States of Medan in the first semester of the 2020/2021 Academic Year with the subjects in this study were 10 students of class VIII-3 as a small class test (development), then for the implementation class trial as many as 29 
students of class VIII Plus 1 and 28 students of class VIII Plus 2. The test instrument developed was divided into three packages, each of which amounted to 5 items, namely Question A, Question B, and Question C which were distributed to each student according to their serial number. The reason for dividing the questions into three packages is because it is not efficient for a student to work on 15 HOTS questions within 2 hours of lessons.

In this study, the ADDIE modeling procedure was applied which consisted of five stages, namely (A) analysis, (D) design, (D) development, (I) implementation, and (E) evaluation. The five procedures in the ADDIE model need to be carried out systematically, which are briefly described in stages according to Branch (2009) in Wulan S, et al (2017, p.40) as shown in Figure 1. below:

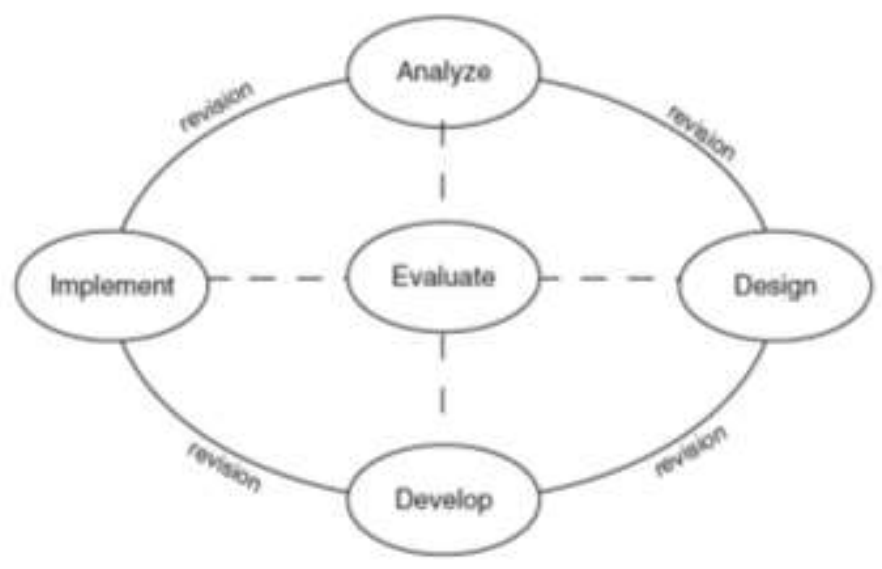

Figure 1. Stages of the ADDIE Model

Based on Figure 1, the first stage is analysis, the researcher analyzes the need for product development, analyzes the feasibility and development requirements, the second stage is planning, the researcher plans the preparation of the test instrument grid, test instrument, and alternative completion of the mathematical High Order Thinking Skill (HOTS) test instrument. In the third stage, namely the development stage, where at this stage the researcher conducts expert validation and analyzes the validation results of the test instruments that have been developed and provides a questionnaire response to the test instrument to the teacher and small class trials. Furthermore, in the fourth stage, namely implementation, the researchers conducted the testing phase of the test instrument in large classes. In the last stage, namely evaluation, researchers evaluate each stage starting from analysis, design, and development. Evaluation can be classified into the formative evaluation and summative evaluation. Evaluation is used to assess the process and test instruments developed. 


\section{Research Instruments}

To measure the validity, reliability, level of difficulty, and differentiating power of the development of the High Order Thinking Skill (HOTS) test instrument, several research instruments are needed. The instruments used in this study are as follows.

1. The test instrument developed is based on HOTS. The tests that will be given are High Order Thinking Skill questions because to measure students' high-level mathematical thinking skills, questions that include indicators of analyzing, evaluating, and creating are used. The test instrument was used to obtain data about students' higher-order mathematical thinking skills.

2. Expert validation sheet. Some of the validation sheets used are the width of the mathematical High Order Thinking Skill (HOTS) test instrument validation. The results of this test instrument validation sheet are used as a basis for evaluating the developed test instrument.

3. Instrument response of students and teachers. This response sheet is used to obtain data about the statements and opinions of students and teachers on the developed test instrument. This instrument is used when in the development stage of ADDIE, which will be used as the basis for product improvements that will be developed at a later stage.

\section{Test Item Quality Analysis}

(1) Expert validation data analysis

In the data from the test instrument validation results, the rating scale criteria will be found, namely: 1 (poor), 2 (good enough), 3 (good), and 4 (very good). Based on the opinion of 5 experts, it can be determined the average value for each aspect, so that the average value of the total aspects is obtained. The activity of determining the average value of the total aspect of assessing the validity of the mathematical High Order Thinking Skill (HOTS) test instrument follows the following steps:

$$
\text { score percentage }=\frac{\text { number of scores per indicator }}{\text { maximum number of indicators }} \times 100 \%
$$

(2) Analysis of the validity of each test item

According to Sugiyono (2017, p.200) to find the coefficient value can be obtained from the product moment correlation formula. The test instrument is said to meet the valid indicators if the higher-order mathematical thinking test instrument developed is at least in the category $85 \%<x \leq 100 \%$ (can be used without revision). 
160 Development Of Test Instruments To Measure High Order Thinking Skill (Hots) Mathematics Of Students In MTs 2 States Of Medan City

$$
r=\frac{n \sum x y-\left(\sum x\right)\left(\sum y\right)}{\sqrt{\left\{n \sum x^{2}-\left(\sum x\right)^{2}\right\}\left\{n \sum y^{2}-\left(\sum y\right)^{2}\right\}}}
$$

Information:

$\mathrm{x}$ : student score on an item

$\mathrm{y}:$ student scores on all items

Furthermore, to test the significance of the validity correlation coefficient, it was carried out by means of the t-test, according to Riduwan (2012) in Jannah et al (2017, p.80) with the formula:

$$
t_{\text {count }}=\frac{r \sqrt{n-2}}{\sqrt{1-r^{2}}}
$$

Information:

$\mathrm{r}$ : correlation coefficient, the result of $\mathrm{r}$ count

$\mathrm{n}$ : many respondents of the trial

The $t$ value obtained from this calculation is then compared with the $t$ value from the table at a certain level of confidence. Distribution (Table t) for $\alpha=0,05$ and degrees of freedom $(\mathrm{dk}=\mathrm{n}-2)$. This validity test is carried out on each item with a decision rule if $t_{\text {count }} \geq t_{\text {table }}$ means valid.

(3) Reliability analysis

The test instrument is said to meet the reliability indicator if the higher-order mathematical thinking test instrument developed is at least in the category $0,6 \leq \mathrm{r} \leq 0,8$ (high test reliability). If a test score is reliable, then the score can be used for various purposes (Dewi, 2017). According to Sugiyono (2017, p.27) for the measuring instrument in the form of a description, the Cronbach Alpha formula is used as follows.

$$
r=\left[\frac{k}{k-1}\right]\left[\frac{s_{t}^{2}-\sum s_{i}^{2}}{s_{t}^{2}}\right]
$$

Information:

$\mathrm{r}$ : reliability coefficient

$\mathrm{k}$ : the number of questions

$\mathrm{s}_{\mathrm{i}}:$ standard deviation of the $\mathrm{i}$-th test item

$\mathrm{s}_{\mathrm{t}}:$ standard deviation of all test items

(4) Difficulty level analysis

The difficulty index (IK) of a test item describes the degree of the proportion of the 
number of correct answer scores on the test item in question to the number of ideal scores. According to Salmina et al (2017, p.43), the test item difficulty index (IK) about the form of constructed response or description is calculated using the following formula.

$$
I K=\frac{\text { average score of students }}{\text { maximum score of an item }}
$$

The item difficulty index was classified as: very easy, easy, moderate, difficult, or very difficult. The test instrument is said to be proportional if the higher-order mathematical thinking test instrument developed is in the category $0,30<I K \leq 0,70$ (medium test item difficulty index).

(5) Differential power analysis

The items on the test instrument can be said to be good if the test items have a minimal discrepancy. This shows that the items have sufficient discriminatory power $0,2 \leq$ DB $<0,4$. Calculations to determine the number of upper and lower groups can be seen $27 \%$ of the number of students. The calculation of the differentiating power of the test items uses the following formula.

$$
D B=\frac{S_{A}-S_{B}}{J_{A}}
$$

(Safitri et al, 2019)

Information:

$\mathrm{S}_{\mathrm{A}}:$ total group score on an item

$\mathrm{S}_{\mathrm{B}}$ : total score of the bottom group of an item

$\mathrm{J}_{\mathrm{A}}$ : the number of ideal scores of an item

\section{RESULTS AND DISCUSSION}

Based on the previous description, the product developed was in the form of a test instrument to measure students' higher-order thinking skills on the material of number patterns, sequences, and series. This test instrument was developed using the ADDIE development model. This test instrument was developed with the general aim of knowing the high-order mathematical thinking skills of class VIII MTs 2 States of Medan on the subject matter of Number Patterns, Sequences, and Series and the specific purpose of this development research was to produce test instruments that were valid, reliable, level of difficulty, and good discrimination.

The validation of the test instrument was seen from the assessment of the five experts, each of whom assessed the components of the construct, language, and context of 
the developed test instrument. The results of the test instrument validation are statements from experts that this test instrument is feasible to be tested with several revisions or suggestions for improvement. In addition, from the results of the test instrument validation, quantitative data was obtained which showed that the developed test instrument scored $91 \%$ with a very valid category.

After the test instrument was validated, then the test instrument was assessed through a teacher response questionnaire and a small class, each given to one teacher, and 10 students, to see the results of the responses that were used as the basis for product improvements to be developed at a later stage. From the results of the two stages, respondents were asked to respond to the available response questionnaires with the results of the responses being stated to be quantitative at $87.5 \%$ and $97.5 \%$, both of these results indicate that the score of more than $50 \%$ of respondents gave a positive response which means the instrument test can be used without revision. After conducting the assessment stage of the test instrument by the teacher and small class trials, then the test instrument was tested on the actual class, which was 57 students.

The following is a formative evaluation that has been carried out by researchers:

\section{Analysis Phase}

The first stage of research on the development of this test instrument is analysis, the researcher chooses a school to be used as a research location but the school is still accredited $\mathrm{B}$ after a discussion with the supervisor given input not to choose a school with low accreditation and it is better to choose a school that is operated/provided by the government, so the researchers chose a research school that was accredited A and operated/provided by the government, namely MTs 2 States of Medan which has become the research location.

\section{Design Phase}

At this stage, the researcher has designed a grid of test instruments and test instruments for the subject matter of statistics where the material is even semester material, but one of the lecturers who gave suggestions for researchers and the research class teacher suggested changing the material according to the material to be studied in the odd semester, namely the material pattern of numbers, sequences, and series. So the researchers designed a grid of test instruments, test instruments, and new alternative solutions, namely on the subject matter of number patterns, sequences, and series. 
The author in designing the test instrument developed by adopting the TIMSS,

PISA, OSN, and HOTS question banks and then modifying them. The following is the

design carried out by researchers to develop a test instrument presented in Table 1.

Table 1. Design of Each Item of Test Instruments

\begin{tabular}{|c|c|c|c|c|c|c|c|}
\hline No & \multicolumn{5}{|c|}{ Origin } & Modific & IIOI \\
\hline $1 \mathrm{~A}$ & \multicolumn{5}{|c|}{$\begin{array}{l}\text { Source: HOTS Question Bank } \\
\text { The production of batik in a batik } \\
\text { village increases every month. The } \\
\text { production of batik in the first month } \\
\text { was } 300 \text { pieces and in the third } \\
\text { month as many as } 1,200 \text { pieces. The } \\
\text { results of the batik production for } \\
\text { one semester are ... }\end{array}$} & $\begin{array}{l}\text { Modified to ask for the } \\
\text { blunt height of } 12 \text { seats. } \\
\text { The reason for the } \\
\text { modification is so that } \\
\text { students can more easily } \\
\text { imagine the object in } \\
\text { question. }\end{array}$ & $\begin{array}{l}\text { Mr. Yoyok stacked chairs of the same } \\
\text { size that were } 100 \mathrm{~cm} \text { each. The stack } \\
\text { height of } 4 \text { chairs is } 118 \mathrm{~cm} \text {. What is } \\
\text { the height of the stack of } 12 \text { chairs? }\end{array}$ \\
\hline $2 \mathrm{~A}$ & \multicolumn{5}{|c|}{$\begin{array}{l}\text { Source: TIMSS } 1999 \\
\text { The three figures below are divided } \\
\text { into small congruent triangles }\end{array}$} & $\begin{array}{l}\text { The original problem } \\
\text { requires students to find } \\
\text { the number of triangles } \\
\text { from a flat square shape, } \\
\text { modified to find the } \\
\text { number of balls that are } \\
\text { collected to form a } \\
\text { rectangle. }\end{array}$ & $\begin{array}{l}\begin{array}{l}\text { Take a look at the following } \\
\text { volleyball }\end{array} \\
\text { sets. } \\
\text { I number of volleyballs on the 30th } \\
\text { The number is... }\end{array}$ \\
\hline \multirow[t]{4}{*}{$3 \mathrm{~A}$} & \multicolumn{5}{|c|}{$\begin{array}{l}\text { Source: TIMSS } 2003 \\
\text { Betty, Frank and Darlene have just } \\
\text { moved to Zedland. They each need } \\
\text { to get phone service. They received } \\
\text { the following information from the } \\
\text { telephone company about the two } \\
\text { different phone plans it offers. } \\
\text { They must pay a set fee each month } \\
\text { and there are different rates for each } \\
\text { minute they talk. These rates depend } \\
\text { on the time of the day or night they } \\
\text { use the phone, and on which } \\
\text { payment plan they choose.both plans } \\
\text { include time for which phone calls } \\
\text { are free. Details of the two plans are } \\
\text { shown in the table below. }\end{array}$} & \multirow{4}{*}{$\begin{array}{l}\text { The problem of origin } \\
\text { requires students to } \\
\text { compare the cheapest } \\
\text { prices for telephone costs, } \\
\text { modified to design } \\
\text { equations to find out the } \\
\text { cheapest ticket prices. } \\
\text { The reason for the } \\
\text { modification, besides being } \\
\text { required to compare, at the } \\
\text { evaluation level must meet } \\
\text { the ability to analyze and } \\
\text { design. The design } \\
\text { required in the matter of } \\
\text { modification is to design } \\
\text { an equation of the existing } \\
\text { problem. }\end{array}$} & \multirow{4}{*}{$\begin{array}{l}\text { OSIM, a madrasah, holds an art } \\
\text { performance for charity which is } \\
\text { open to the general public. The } \\
\text { committee chose a venue in the form } \\
\text { of a theater where the audience } \\
\text { seating was in the form of a circular } \\
\text { sector consisting of six rows. If the } \\
\text { first row has } 25 \text { seats, the second row } \\
\text { has } 35 \text { seats, the third row has } 50 \\
\text { seats, the fourth row has } 70 \text { seats, and } \\
\text { so on. The number of spectator seats } \\
\text { in each row forms a certain row } \\
\text { pattern. } \\
\text { If the ticket price for the first row is } \\
\text { the most expensive ticket and the } \\
\text { difference in ticket prices between } \\
\text { two adjacent rows is IDR } 10,000, \\
\text { assuming all audience seats are fully } \\
\text { occupied. What is the cheapest ticket } \\
\text { price so that the committee can get an } \\
\text { income of Rp. } 22,500,000 \text { ? }\end{array}$} \\
\hline & & Iy feee & 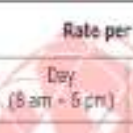 & $\frac{\text { minste }}{\substack{\text { mintt } \\
(6 \mathrm{~mm}-8 \mathrm{ann})}}$ & $\begin{array}{c}\text { Free minutes } \\
\text { per month }\end{array}$ & & \\
\hline & Fan $A$ & & & and & & & \\
\hline & Pan $\mathrm{B}$ & & $2 \mathrm{kts}$ & $2 \cos 5$ & 120 & & \\
\hline $4 \mathrm{~A}$ & \multicolumn{5}{|c|}{ Source: TIMSS 2003} & $\begin{array}{l}\text { The original question asked } \\
\text { for the } 10^{\text {th }} \text { pattern, }\end{array}$ & $\begin{array}{l}\text { Each of the following triangles is } \\
\text { made up of } 3 \text { sticks. Considering the }\end{array}$ \\
\hline
\end{tabular}




\begin{tabular}{|c|c|c|c|}
\hline & 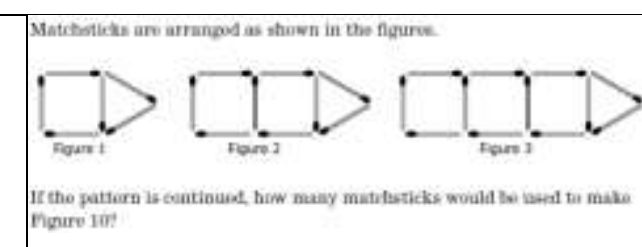 & $\begin{array}{l}\text { modified to 100th and } \\
\text { modified the arrangement } \\
\text { of the sticks. }\end{array}$ & $\begin{array}{l}\text { ng pattern, how man } \\
\text { in the 100th }\end{array}$ \\
\hline \multicolumn{2}{|r|}{ A $\begin{array}{l}\text { Source: OSN SMP } \\
\text { If value } 100 \mathrm{~B}=100^{2}+99^{2}-98^{2}- \\
97^{2}+\cdots+4^{2}+3^{2}-2^{2}-1^{2}, \text { then } \\
\text { the value of B is } \ldots\end{array}$} & $\begin{array}{l}\text { The problem of the origin } \\
\text { of the numbers calculated } \\
\text { from } 1 \text { to } 100 \text {, modified to } \\
\text { be from } 1 \text { to } 2011 \text {. }\end{array}$ & $\begin{array}{l}1^{2}-2^{2}+3^{2}-4^{2}+5^{2} \\
\quad-\ldots-2010^{2}+2011^{2} \\
\text { The sum of the following numbers } \\
\text { is... }\end{array}$ \\
\hline 1B & $\begin{array}{l}\text { Source: HOTS Question Bank } \\
\text { A private employee receives a salary } \\
\text { in the first year of Rp. } 3,000,000 . \\
\text { Every year the employee's salary } \\
\text { increases. If the amount of money } \\
\text { received by the employee for } 10 \\
\text { years is RP. } 52,500,000 \text {, then the } \\
\text { increase in the employee's salary } \\
\text { each month is .... }\end{array}$ & $\begin{array}{l}\text { The question of asking for } \\
\text { a month's salary increase } \\
\text { was modified to ask when } \\
\text { the } 40 \% \text { of the bonus } \\
\text { received was from the first- } \\
\text { year bonus. The reason for } \\
\text { the modification is because } \\
\text { if you only ask for a } \\
\text { month's salary increase, it } \\
\text { does not require the ability } \\
\text { to analyze. }\end{array}$ & $\begin{array}{l}\text { Mr. Tarno is an employee of PT. Jaya } \\
\text { Abadi who received the first annual } \\
\text { bonus of Rp. 3,000,000. Every year } \\
\text { the bonus received will increase by } \\
\text { Rp. 200,000. In which year did Mr. } \\
\text { Tarno's bonus increase by } 40 \% \text { from } \\
\text { the first year's bonus? }\end{array}$ \\
\hline 21 & $\begin{array}{l}\text { Sumber: TIMSS } 1999 \\
\text { If the pattern on the grid below was } \\
\text { continued, ehat letter would identify } \\
\text { the orientation of the tile in the cell } \\
\text { labeled X? }\end{array}$ & $\begin{array}{l}\text { The original problem } \\
\text { predicts the pattern that is } \\
\text { at } x \text {, modified to predict } \\
\text { the next pattern from the } \\
\text { previous pattern. } \\
\text { The reason for the } \\
\text { modification is that it } \\
\text { requires the ability to make } \\
\text { hypotheses in } 2 \text { parts, the } \\
\text { first part is the big pictures } \\
\text { and the second part is the } \\
\text { small picture. }\end{array}$ & $\begin{array}{l}\text { How is the image model in the 6th } \\
\text { pattern? }\end{array}$ \\
\hline $3 B$ & $\begin{array}{l}\text { Source: HOTS Question Bank } \\
\text { A private employee receives a salary } \\
\text { in the first year of Rp. } 3,000,000 \text {. } \\
\text { Every year the employee's salary } \\
\text { increases. If the amount of money } \\
\text { received by the employee for } 10 \\
\text { years is RP. } 52,500,000 \text {, then the } \\
\text { increase in the employee's salary } \\
\text { each month is .... }\end{array}$ & $\begin{array}{l}\text { The original question asked } \\
\text { for a monthly salary } \\
\text { increase, modified to } \\
\text { compose, and correct the } \\
\text { hypothesis being asked. } \\
\text { The reason for the } \\
\text { modification is to meet the } \\
\text { demands of ability at the } \\
\text { level of evaluation. }\end{array}$ & $\begin{array}{l}\text { Mr. Hadid is an employee at an } \\
\text { insurance company who is } 40 \text { years } \\
\text { old. This year, he became a manager } \\
\text { and he got a salary increase of Rp. } \\
750.000,- \text { annually so that this year he } \\
\text { got a salary of Rp. } 15.75 \text { million, - per } \\
\text { month. Next year his salary will } \\
\text { increase again to Rp. } 16,500,000 \text { per } \\
\text { month. If the retirement limit at the } \\
\text { insurance company is } 60 \text { years and it } \\
\text { is assumed that Mr. Hadid will serve } \\
\text { as manager until he retires. Has Mr. } \\
\text { Hadid ever received a minimum } \\
\text { salary of IDR } 32,000,000 \text { per month? } \\
\text { If so at what age did he get it? }\end{array}$ \\
\hline $4 B$ & $\begin{array}{l}\text { Source: HOTS Question Bank } \\
\text { At the beginning of every month, the } \\
\text { father divides the amount of money } \\
\text { among his } 5 \text { children. The money to } \\
\text { be distributed consists of two }\end{array}$ & $\begin{array}{l}\text { Regarding the origin of } \\
\text { asking the money that the } \\
\text { father distributed to his } \\
\text { son, the question was } \\
\text { modified to how much }\end{array}$ & $\begin{array}{l}\text { Father divided the allowance as much } \\
\text { as Rp. } 300,000 \text { to their } 4 \text { children. If } \\
\text { the difference in money received by } 2 \\
\text { children who are close in age is Rp. } \\
15,000 \text {. If the youngest received the }\end{array}$ \\
\hline
\end{tabular}




\begin{tabular}{|c|c|c|c|}
\hline & $\begin{array}{l}\text { thousand bills. The first child gets } 48 \\
\text { pieces and the second child gets half } \\
\text { of the first child, the third child gets } \\
\text { half of the second child, and so on. } \\
\text { The amount of money that father } \\
\text { distributed was.... }\end{array}$ & $\begin{array}{l}\text { money one of the children } \\
\text { received. The reason for } \\
\text { the modification in order to } \\
\text { meet the demands of } \\
\text { ability at the level of } \\
\text { evaluating is to make } \\
\text { hypotheses and test them. }\end{array}$ & $\begin{array}{l}\text { least, how much money did the third } \\
\text { child receive? }\end{array}$ \\
\hline $5 B$ & $\begin{array}{l}\text { Source: PISA } 2014 \\
\text { Rohman made a staircase pattern } \\
\text { using several squares. The following } \\
\text { are some of the steps he goes } \\
\text { through. } \\
\text { As shown in the figure, he used one } \\
\text { square in Stage 1, three squares in } \\
\text { Stage 2, and six squares for Stage } 3 \text {. } \\
\text { How many squares did he use for } \\
\text { stage four? }\end{array}$ & $\begin{array}{l}\text { The original problem } \\
\text { shows a pattern by } \\
\text { arranging a square into a } \\
\text { ladder, modified into a } \\
\text { circle bounded by a red } \\
\text { line. }\end{array}$ & $\begin{array}{l}\text { By paying attention to the circles } \\
\text { bordered by red lines. } \\
\text { How many circles are in the 100th } \\
\text { pattern? }\end{array}$ \\
\hline $1 \mathrm{C}$ & $\begin{array}{l}\text { Source: HOTS Question Bank } \\
\text { The production of batik in a batik } \\
\text { village increases every month. The } \\
\text { production of batik in the first month } \\
\text { was } 300 \text { pieces and in the third } \\
\text { month as many as } 1,200 \text { pieces. The } \\
\text { results of the batik production for } \\
\text { one semester are .... }\end{array}$ & $\begin{array}{l}\text { The question of origin } \\
\text { asking for production } \\
\text { results for one semester, } \\
\text { was modified to ask for a } \\
\text { lot of production in the 8th } \\
\text { month. }\end{array}$ & $\begin{array}{l}\text { A factory in the first month produces } \\
6000 \text { units of goods and the total } \\
\text { production for one semester is } 42,000 \\
\text { units, the number of production in the } \\
\text { eighth month is .... }\end{array}$ \\
\hline $2 \mathrm{C}$ & $\begin{array}{l}\text { Source: TIMSS } 2007 \\
\text { Posters for two sports clubs that rent } \\
\text { bikes are shown below. }\end{array}$ & $\begin{array}{l}\text { The problem of origin is } \\
\text { the cheapest cost between } \\
2 \text { bicycle rental shops, } \\
\text { modified to the largest } \\
\text { salary obtained from the } 2 \\
\text { choices. }\end{array}$ & $\begin{array}{l}\text { Mr. Wahyu is contracted to work for } \\
\text { a company for } 7 \text { days. Before starting } \\
\text { work, he was asked to choose } \\
\text { between options (1) being given a } \\
\text { salary of Rp. } 75,000,- \text { per day for a } \\
\text { week, or option (2) being given a } \\
\text { salary of Rp. } 10,000 \text {, - on the first day } \\
\text { and doubled every day for a week. } \\
\text { Which is the best choice for Mr. } \\
\text { Wahyu to choose? }\end{array}$ \\
\hline $3 \mathrm{C}$ & $\begin{array}{l}\text { Source: TIMSS } 2011 \\
\text { If there were a Figure 5, how many } \\
\text { circles would it have? }\end{array}$ & $\begin{array}{l}\text { Modify the arrangement of } \\
\text { marbles and modify the } \\
\text { question on the number of } \\
\text { terms. }\end{array}$ & 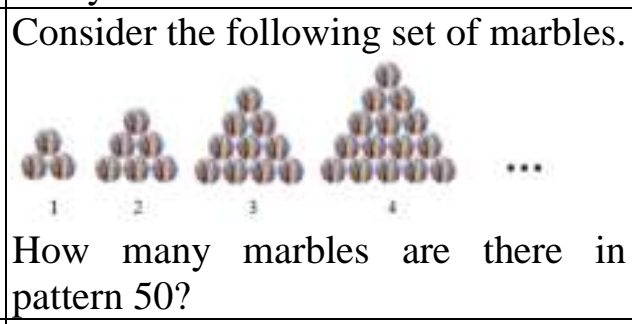 \\
\hline $4 \mathrm{C}$ & 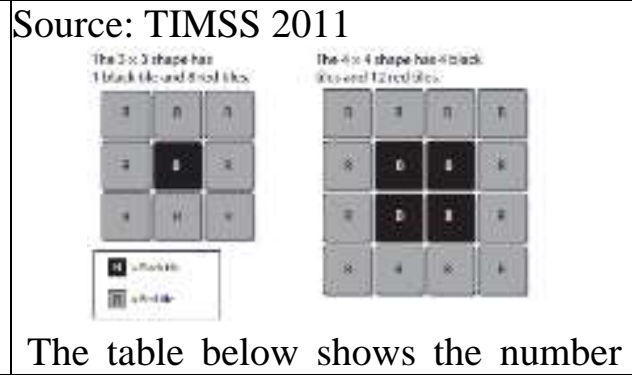 & $\begin{array}{l}\text { Modify the number of } \\
\text { black tiles and red tiles in } \\
\text { each square. }\end{array}$ & $\begin{array}{l}\text { Look at the following picture. } \\
\text { How many red candies are in the } \\
\text { tenth picture? }\end{array}$ \\
\hline
\end{tabular}




\begin{tabular}{|c|c|c|c|}
\hline & $\begin{array}{l}\text { of tiles for the first three shapes Pat } \\
\text { made. Pat continued making shapes } \\
\text { using this pattern. Complete the } \\
\text { table for the } 6 \times 6 \text { and } 7 \times 7 \text { shapes. }\end{array}$ & & \\
\hline $5 \mathrm{C}$ & $\begin{array}{l}\text { Source: HOTS Question Bank } \\
\text { A cake is in the shape of a circle } \\
\text { with a diameter of } 25 \mathrm{~cm} \text {. The cake } \\
\text { will be cut into } 10 \text { square pieces. } \\
\text { The central angles of the } 10 \text { pieces } \\
\text { of the cake form an arithmetic } \\
\text { sequence. If the size of the corner of } \\
\text { the smallest piece of cake is } \frac{1}{6} \text { of the } \\
\text { size of the center of the largest piece } \\
\text { of cake, the area of the largest piece } \\
\text { of cake is .... }\end{array}$ & $\begin{array}{l}\text { The original question asked } \\
\text { for the area of the largest } \\
\text { piece of cake, modified to } \\
\text { ask for the highest number } \\
\text { of shellfish in one cup. The } \\
\text { reason for the modification } \\
\text { to meet the demands of } \\
\text { ability at the level of } \\
\text { creation is to consider the } \\
\text { incoming information. }\end{array}$ & $\begin{array}{l}\text { One hundred marbles will be placed } \\
\text { in } 10 \text { different cups. Each cup } \\
\text { contains a different number of } \\
\text { marbles. For the number of marbles in } \\
\text { each cup to form an arithmetic series, } \\
\text { what is the maximum number of } \\
\text { marbles that can be placed in one } \\
\text { cup? }\end{array}$ \\
\hline
\end{tabular}

To make this test instrument more attractive to present, the researcher designed the cover of the test instrument, instructions for use, and the contents of the test instrument. The results of the test instrument design are presented in Table 2.:

Table 2. Initial Design of Test Instruments

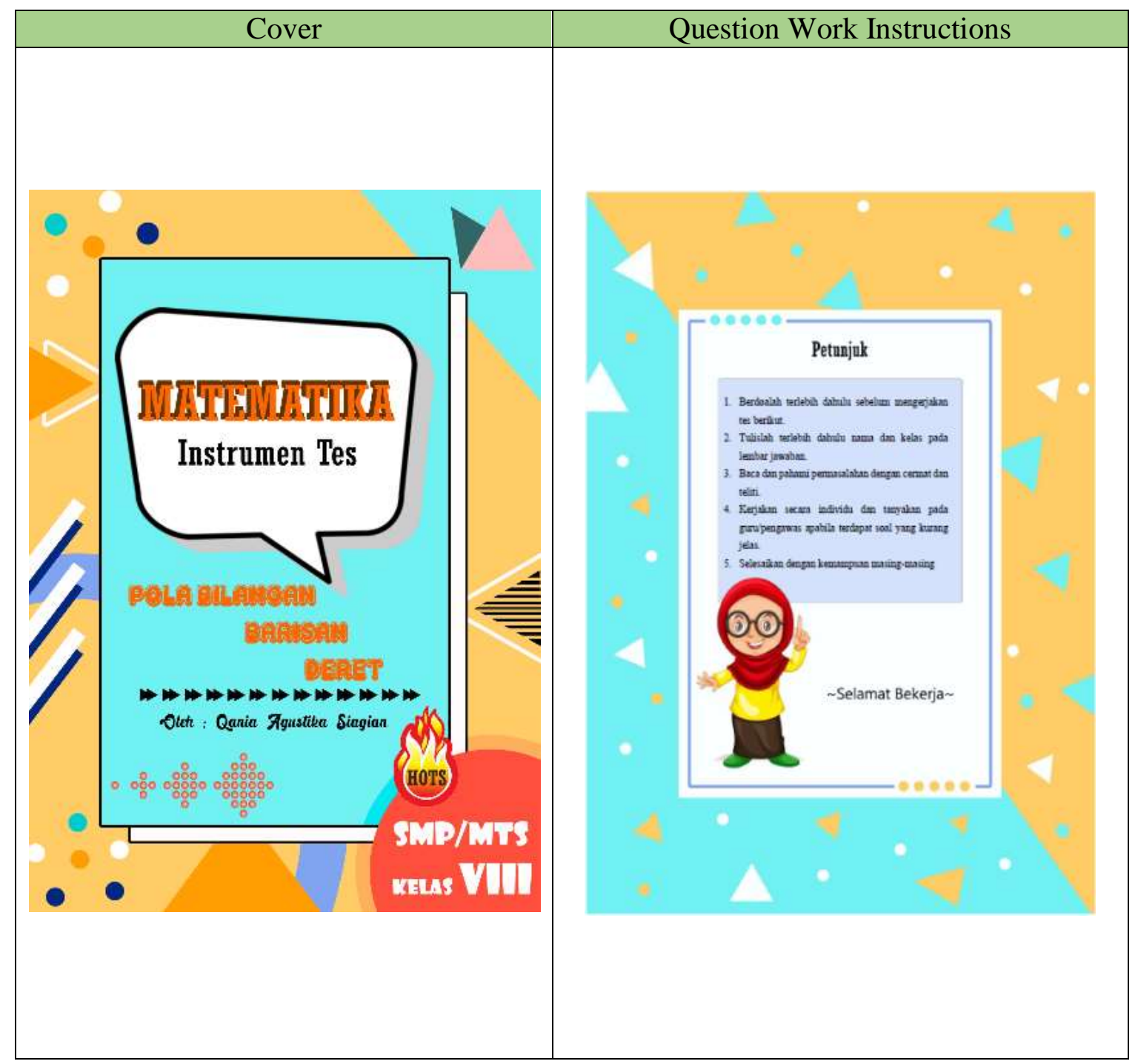




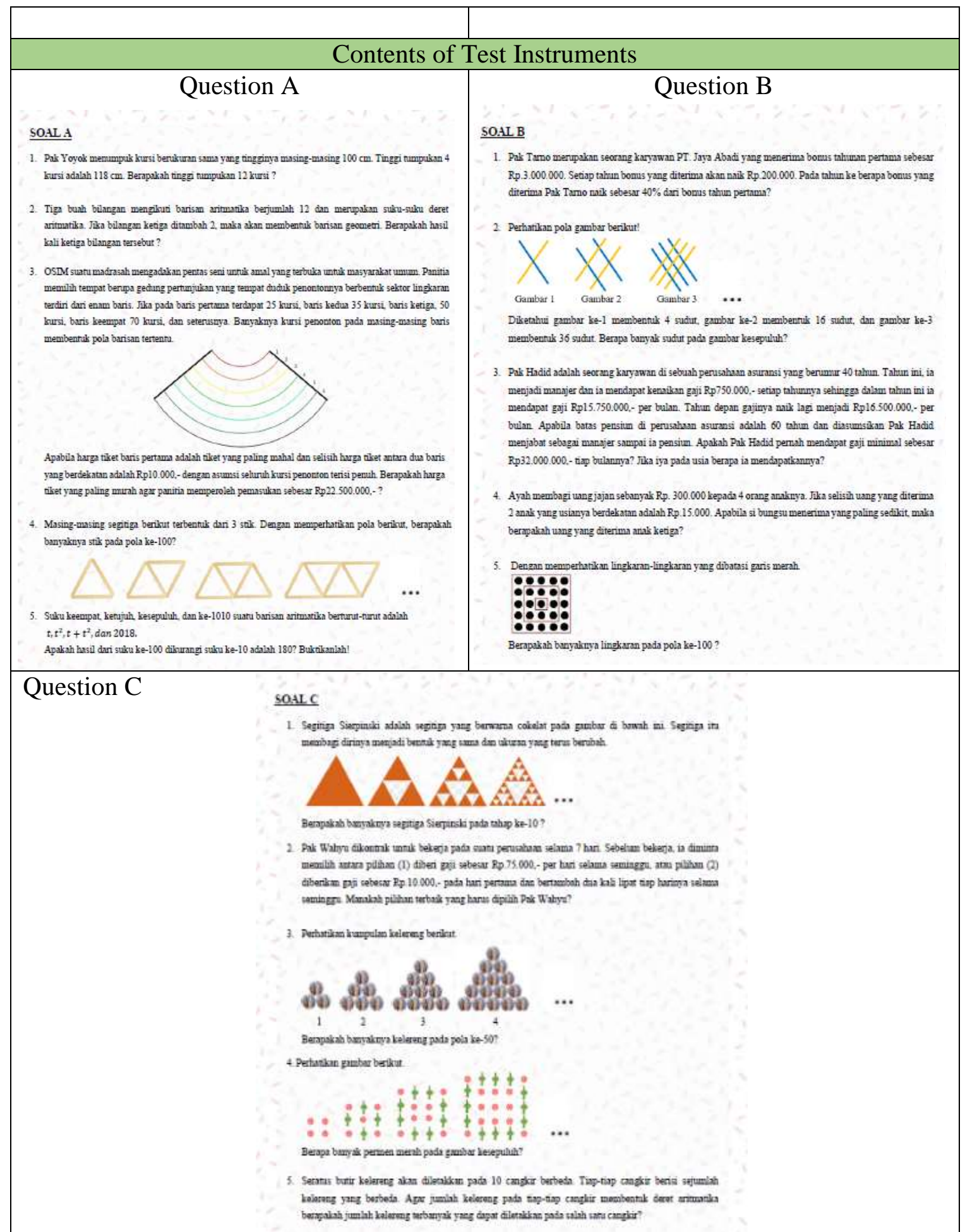

\section{Development Phase}

At this stage, the researchers made improvements to the quality of the test instruments through a validation process according to the directions of the validators and small class test response questionnaire analysis. From the results of the expert validation sheets, there are several questions that are recommended to be improved, such as in numbers $2 \mathrm{~A}, 4 \mathrm{~A}, 5 \mathrm{~A}, 1 \mathrm{~B}, 2 \mathrm{~B}, 3 \mathrm{~B}, 1 \mathrm{C}, 3 \mathrm{C}$, and $4 \mathrm{C}$. From the results of the student response 
questionnaire, students were asked to color the pictures that were not colored, so the writer corrected the test by coloring the pictures that were not colored.

The results of the test instruments that have been validated by experts and the reasons for each test item can be categorized as HOTS questions which are presented in Table 3. below:

Table 3. HOTS Indicators Required in Each Test Item

\begin{tabular}{|c|c|c|c|}
\hline No & Question & $\begin{array}{c}\text { HOTS } \\
\text { Indicator }\end{array}$ & Information \\
\hline $1 \mathrm{~A}$ & $\begin{array}{l}\text { Mr. Yoyok stacked chairs of the same size } \\
\text { that were } 100 \mathrm{~cm} \text { each. The stack height of } 4 \\
\text { chairs is } 118 \mathrm{~cm} \text {. What is the height of the } \\
\text { stack of } 12 \text { chairs? }\end{array}$ & C4 & $\begin{array}{l}\text { Analyzing that the problem has a } \\
\text { difference is always constant, which is } \\
\text { called an arithmetic sequence. } \\
\text { Formulate the problem that the same } \\
\text { sized chair whose height is } 100 \mathrm{~cm} \text { is } \\
\text { the first term. }\end{array}$ \\
\hline $2 \mathrm{~A}$ & $\begin{array}{l}\text { Three numbers following an arithmetic } \\
\text { sequence add up to } 12 \text { and are terms of an } \\
\text { arithmetic series. If the third number is added } \\
\text { by } 2 \text {, it will form a geometric sequence. What } \\
\text { is the product of these three numbers? }\end{array}$ & C4 & $\begin{array}{l}\text { Correlate between arithmetic sequences } \\
\text { and geometric sequences. }\end{array}$ \\
\hline $3 \mathrm{~A}$ & $\begin{array}{l}\text { OSIM, a madrasah, holds an art performance } \\
\text { for charity which is open to the general public. } \\
\text { The committee chose a venue in the form of a } \\
\text { theater where the audience seating was in the } \\
\text { form of a circular sector consisting of six rows. } \\
\text { If the first row has } 25 \text { seats, the second row } \\
\text { has } 35 \text { seats, the third row has } 50 \text { seats, the } \\
\text { fourth row has } 70 \text { seats, and so on. The } \\
\text { number of spectator seats in each row forms a } \\
\text { certain row pattern. } \\
\text { If the ticket price for the first row is the most } \\
\text { expensive ticket and the difference in ticket } \\
\text { prices between two adjacent rows is IDR } 10,000 \text {, } \\
\text { assuming all audience seats are fully occupied. } \\
\text { What is the cheapest ticket price so that the } \\
\text { committee can get an income of Rp. } 22,500,000 \text { ? }\end{array}$ & C5 & $\begin{array}{l}\text { Analyze the problem that the number of } \\
\text { seats between rows has a pattern. } \\
\text { Designing an appropriate equation to } \\
\text { find out the cheapest ticket prices on the } \\
\text { condition that the first line ticket price is } \\
\text { the most expensive and there is a } \\
\text { difference in ticket prices between two } \\
\text { adjacent rows. }\end{array}$ \\
\hline $4 \mathrm{~A}$ & $\begin{array}{l}\text { Each of the following triangles is made up of } 3 \\
\text { sticks. Considering the following pattern, how } \\
\text { many sticks are in the 100th pattern? }\end{array}$ & C6 & $\begin{array}{l}\text { Predict/weigh/find patterns formed from } \\
\text { pictures. }\end{array}$ \\
\hline $5 \mathrm{~A}$ & $\begin{array}{l}\text { The fourth, seventh, tenth, and 1010th terms } \\
\text { of an arithmetic sequence are } \\
\qquad t, t^{2}, t+t^{2} \text {, dan } 2018 \text {. } \\
\text { Is the result of the } 100 \text { th term minus the 10th } \\
\text { term } 180 \text { ? Prove it! }\end{array}$ & C6 & $\begin{array}{l}\text { Verify the information entered. Is it true } \\
\text { that the result of the 100th term minus } \\
\text { the 10th term is } 180 ?\end{array}$ \\
\hline
\end{tabular}




\begin{tabular}{|c|c|c|c|}
\hline $1 \mathrm{~B}$ & $\begin{array}{l}\text { Mr. Tarno is an employee of PT. Jaya Abadi } \\
\text { who received the first annual bonus of Rp. } \\
3,000,000 \text {. Every year the bonus received will } \\
\text { increase by Rp. } 200,000 \text {. In which year did } \\
\text { Mr. Tarno's bonus increase by } 40 \% \text { from the } \\
\text { first year's bonus? }\end{array}$ & $\mathrm{C} 4$ & $\begin{array}{l}\text { Find other information such as the value } \\
\text { of } U_{n} \text { that can be searched from the } \\
\text { existing information. }\end{array}$ \\
\hline $2 \mathrm{~B}$ & $\begin{array}{l}\text { Take a look at the following pattern! } \\
\text { It is known that the } 1 \text { st image forms } 4 \text { angles, } \\
\text { the 2nd image forms } 16 \text { angles, and the 3rd } \\
\text { image forms } 36 \text { angles. How many angles are } \\
\text { in the tenth picture? }\end{array}$ & C5 & Design a pattern from the picture. \\
\hline $3 B$ & $\begin{array}{l}\text { Mr. Hadid is an employee at an insurance } \\
\text { company who is } 40 \text { years old. This year, he } \\
\text { became a manager and he got a salary } \\
\text { increase of Rp. } 750.000,- \text { annually so that this } \\
\text { year he got a salary of Rp. } 15.75 \text { million, - } \\
\text { per month. Next year his salary will increase } \\
\text { again to Rp. } 16,500,000 \text { per month. If the } \\
\text { retirement limit at the insurance company is } \\
60 \text { years and it is assumed that Mr. Hadid will } \\
\text { serve as manager until he retires. Has Mr. } \\
\text { Hadid ever received a minimum salary of } \\
\text { IDR } 32,000,000 \text { per month? If so at what age } \\
\text { did he get it? }\end{array}$ & C5 & $\begin{array}{l}\text { Develop hypotheses and correct } \\
\text { hypotheses. }\end{array}$ \\
\hline $4 \mathrm{~B}$ & $\begin{array}{l}\text { Father divided the allowance as much as Rp. } \\
300,000 \text { to their } 4 \text { children. If the difference } \\
\text { in money received by } 2 \text { children who are } \\
\text { close in age is Rp. } 15,000 \text {. If the youngest } \\
\text { received the least, how much money did the } \\
\text { third child receive? }\end{array}$ & $\mathrm{C} 5$ & $\begin{array}{l}\text { Designing known information, such as } \\
\text { the statement that the youngest received } \\
\text { the least, said the youngest means that } \\
\text { the child is the } 4^{\text {th }} \text { or } 4^{\text {th }} \text { tribe. }\end{array}$ \\
\hline $5 B$ & $\begin{array}{l}\text { By paying attention to the circles bordered by } \\
\text { red lines. }\end{array}$ & C6 & $\begin{array}{l}\text { Predict/weigh/find patterns formed from } \\
\text { pictures. }\end{array}$ \\
\hline & How many circles are in the 100th pattern? & & \\
\hline $1 \mathrm{C}$ & $\begin{array}{l}\text { The Sierpinski triangle is the brown triangle } \\
\text { in the image below. The triangle divides itself } \\
\text { into equal shapes and constantly changing } \\
\text { sizes. } \\
\text { How many Sierpinski triangles are there in } \\
\text { step 10? }\end{array}$ & $\mathrm{C} 4$ & $\begin{array}{l}\text { Find the pattern in the Sierpinski } \\
\text { triangle. }\end{array}$ \\
\hline $2 \mathrm{C}$ & $\begin{array}{l}\text { Mr. Wahyu is contracted to work for a } \\
\text { company for } 7 \text { days. Before starting work, he }\end{array}$ & $\mathrm{C} 4$ & $\begin{array}{l}\text { Compare the statement of choice (1) } \\
\text { with choice (2). }\end{array}$ \\
\hline
\end{tabular}




\begin{tabular}{|c|c|c|c|}
\hline & $\begin{array}{l}\text { was asked to choose between options (1) } \\
\text { being given a salary of Rp. } 75,000,- \text { per day } \\
\text { for a week, or option ( } 2 \text { ) being given a salary } \\
\text { of Rp. } 10,000,- \text { on the first day and doubled } \\
\text { every day for a week. Which is the best } \\
\text { choice for Mr. Wahyu to choose? }\end{array}$ & & \\
\hline $3 \mathrm{C}$ & 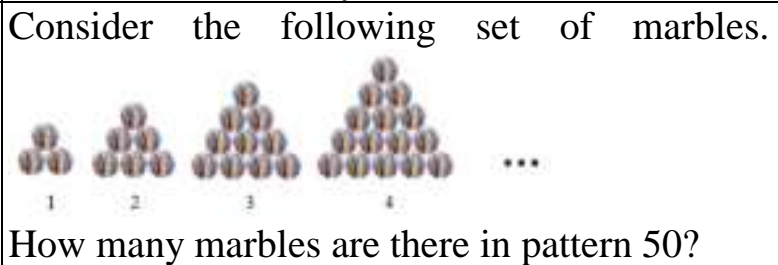 & C5 & Predict the pattern of the set of marbles. \\
\hline $4 \mathrm{C}$ & $\begin{array}{l}\text { Look at the following picture. } \\
\text { How many red candies are in the tenth } \\
\text { picture? }\end{array}$ & C6 & $\begin{array}{l}\text { Predict/weigh/find patterns formed from } \\
\text { pictures. }\end{array}$ \\
\hline $5 \mathrm{C}$ & $\begin{array}{l}\text { One hundred marbles will be placed in } 10 \\
\text { different cups. Each cup contains a different } \\
\text { number of marbles. For the number of } \\
\text { marbles in each cup to form an arithmetic } \\
\text { series, what is the maximum number of } \\
\text { marbles that can be placed in one cup? }\end{array}$ & C6 & Weighing the incoming information. \\
\hline
\end{tabular}

\section{Implementation Phase}

At this stage, the researcher conducts a summative evaluation, namely the assessment of test instruments to make decisions about the sustainability of a product. Summative evaluation is carried out by knowing the validity and reliability of the test items, the level of difficulty, and the distinguishing power of the developed test instrument.

Based on the results of this study, all items A on this test instrument is said to be valid. The criteria for item numbers 1, 2, 3, and 5 have "High" validity, while item 4 has "Very High" validity. For all items B on this test instrument is said to be valid. For the criteria items, numbers 2 and 5 have "Enough" validity, 1 and 4 have "High" validity, while item number 3 has "Very High" validity. For all items $\mathrm{C}$ on this test instrument is said to be valid. The criteria for items number 1, 2, 4, and 5 have "High" validity, while item number 3 has "Enough" validity.

Judging from the reliability of the test items, item A on this test instrument has "High" reliability of 0.76. For item B on this test instrument has "High" reliability of 0.67. Meanwhile, item $\mathrm{C}$ on this test instrument has "High" reliability of 0.69. Judging from the analysis of the level of difficulty of the items, for all questions A, B, and C, all three have a "Medium" difficulty index. 
Judging from the analysis of discriminating power, for question $\mathrm{A}$ in questions number 1, 2, 3, 4, and 5 have a different power of "Good". For question B on questions number 2, 4, and 5 it has a "good enough" difference power and for questions number 1 and 3 it has a "good" distinguishing power. For question $\mathrm{C}$ on questions number 1, 2, 3, 4, and 5 it has a "Good" distinction.

Table 4. Students' Mathematical High Order Thinking Skill (HOTS) Test Results

\begin{tabular}{|c|c|c|c|}
\hline Score & Frequency & Percentage (\%) & Category \\
\hline $90 \leq$ Score $\leq 100$ & 8 & 14,04 & Very high \\
\hline $75 \leq$ Score $<90$ & 19 & 33,33 & High \\
\hline $55 \leq$ Score $<75$ & 12 & 21,05 & Enough \\
\hline $40 \leq$ Score $<55$ & 11 & 19,3 & Less \\
\hline Score $<40$ & 7 & 12,28 & Very less \\
\hline Number of Subjects & 57 & 100 & Enough \\
\hline Average score & \multicolumn{2}{|c|}{65,09} & \\
\hline
\end{tabular}

Based on the table above, it is known that the students' higher order mathematical thinking skills were found that from 57 subjects there were 8 students $(14.04 \%)$ included in the category of having higher-order mathematical thinking skills in the very high category, 19 students (33.33\%) having higher order thinking skills. high mathematical ability in the high category, 12 students $(21.05 \%)$ have high order mathematical thinking skills in the sufficient category, 11 students $(19.3 \%)$ have high order mathematical thinking skills in the poor category, and 7 students (12.28\%) have high order mathematical thinking skills in the very poor category. So that the average high order mathematical thinking ability of students is $65.09 \%$ with sufficient category. The students' higher order thinking ability is still in the sufficient category because the question is a non-routine question when learning in class with the teacher so far. This was evidenced by the results of one student response questionnaire which said that this test instrument was better for exam questions, this was because they were not familiar with answering HOTS questions.

In line with the research by Budiman and Jailani (2014) in Aisah \& Pahlevi (2020, p.155), one of the causes of below-average student abilities is that students lack practice in working on contextual questions, which require reasoning, argument, and creativity skills. If teachers are able to encourage students to think at a higher level then students will have higher-order thinking skills that will be able to compete in the TIMSS and PISA assessments. 
The responses of the 57 students to the given test instrument showed a positive response. The average shows $94.74 \%$, which means that more than $50 \%$ of students give a positive response, so it can be said that it can be used without revision.

This research is also relevant to the research conducted by Martina (2017) based on the results of the research that the test instrument developed can measure students' HOTS by meeting the quality criteria of the test instrument. These criteria include validity, reliability, level of difficulty, and distinguishing power. Also in line with Nurmadinah's opinion (2017) based on the results of her research that the test instrument developed if it is declared valid, has good reliability, a decent level of difficulty, and not bad discriminating power, the test instrument can measure students' HOTS.

This proves that the test instrument developed is truly appropriate and can be used by a wider range of schools. By fulfilling the stages of testing the validity, reliability, level of difficulty, and discriminating power. So the stage of developing this test instrument has ended.

\section{CONCLUSION}

Based on the results of the previous research and discussion, it can be concluded that 15 questions have been successfully developed which are declared valid, this is the average score of the test instrument assessment by experts of $91 \%$ and the validity of each test item is declared "valid". The reliability of the test instrument for each package of questions was assessed as reliable with a score of $0.76,0.67$, and 0.69 in the high category. In the analysis of the level of difficulty, it appears that the results are in the easy and medium categories. In the analysis of discriminatory power, it appears that the results are quite good and good. The average result of students' higher-order mathematical thinking skills is $65.09 \%$ with sufficient category.

The researcher gives the advice to further researchers, this question can be used as material for consideration to examine more deeply problems of higher-order mathematical thinking skills for other materials so that students are familiar with questions that meet the criteria for higher-order mathematical thinking skills. And the teacher should have provided training in the form of HOTS questions continuously so that students are trained and accustomed to working on HOTS questions so that students can support their ability to think at higher levels. 


\section{THANK-YOU NOTE}

The authors would like to thank Dr. Izwita Dewi, M.Pd., Mr. Mangaratua M. Simanjorang, M.Pd., Ph.D., and Mrs. Glory Indira D. Purba, S.Si., M.Pd., as lecturers in the Mathematics Education Study Program at the University Medan State who has provided advice and direction during the research process so that this research can run smoothly.

\section{REFERENCES}

Aisah, S., \& Pahlevi, T. (2020). Pengembangan Instrumen Penilaian Higher Order Thinking Skills (HOTS) Pada Mata Pelajaran Korespondensi Kelas X OTP di SMK Negeri 1 Jombang. Jurnal Pendidikan Administrasi Perkantoran (JPAP), Vol. 8 (1), 146-156.

Ardhana, T. (2017). Keterampilan Berpikir Siswa Dalam Menyelesaikan Soal Garis Dan Sudut Berdasaran Taksonomi Bloom Revisi. Skripsi. Universitas Muhammadiyah Surakarta: Tidak diterbitkan.

Arifin, Z. (2017). Evaluasi Pembelajaran. Bandung: PT Pemuda Rosdakarya.

Arlianty, W. N., Febriana, B. W., Diniaty, A., \& Fauzi'ah, L. (2018). Student Profile in Completing Questions Based on Cognitive Level of Bloom's Taxonomy By Anderson and Krathwohl. AIP Conference Proceedings, Vol. 2026 (020063), 1-6.

Dewi, R. (2017). Pengembangan Instrumen Tes Untuk Mengukur Kemampuan Komunikasi Matematis Siswa SMP Negeri 17 Makassar. Skripsi. UIN Alauddin Makassar: Tidak diterbitkan.

Fadlila, Nindy. (2019). Pengembangan Instrumen Tes Berbasis Pendidikan Realistik Untuk Meningkatkan High Order Thinking Skill (HOTS) Siswa SMP Muhammadiyah 47 Sunggal T.A. 2018/2019. Skripsi. Universitas Negeri Medan: Tidak diterbitkan.

Febiana, M. V. (2019). Pengembangan Soal HOTS Materi Luas Bangun Datar Dan Volume Bangun Ruang Untuk Siswa Kelas V SD. Skripsi. Santa Dharma University Yogyakarta: Tidak diterbitkan.

Febri E. (2017). Pedoman Metodologi Penelitian. Sidoarjo: Zifatama Jawara.

Hadi, S. (2018). Pendidikan Matematika Realistik dan Implementasinya. Banjarmasin: Tulip.

Hajar, I., Lufri, \& Fauzan A. (2021). Validity Level Analysis Model Pjbl For Biology Learning. Journal of Physics: Conference Series, Vol. 1940 (012125), 1-7.

Jannah, M., Abdi, A. W., \& Harun, M. Y. (2017). Hubungan Pemanfaatan Internet Sebagai Sumber Belajar Dengan Hasil Belajar Geografi Siswa Kelas X Lab School Banda Aceh. Jurnal Ilmiah Mahasiswa Pendidikan Geografi FKIP Unsyiah, Vol. 2 (2), 7891.

Khodaria, S., Maharani, A., \& Sulaiman H. (2019). The Analysis Of Item Problems In High School Mathematics Textbook In Indonesia (2016 Revision Edition) Reviewed From The Cognitive Aspect Of TIMSS. Indonesian Journal of Learning and Instruction, Vol. 2 (1), 65-70.

Kusuma, M. D., Rosidin, U., Abdurrahman, \& Suyatna, A. (2017). The Development of Higher Order Thinking Skill (HOTS) Instrument Assessment In Physics Study. IOSR Journal of Research \& Method in Education, Vol. 7 (1), 26-32. 
174 Development Of Test Instruments To Measure High Order Thinking Skill (Hots) Mathematics Of Students In MTs 2 States Of Medan City

Malik, R. S. (2018). Educational Challenges In 21st Century And Sustainable Developmen. Journal of Sustainable Development Education and Research, Vol 2 (1), 9-20.

Martina. (2017). Pengembangan Instrumen Tes Higher Order Thinking Skill (HOTS) Pokok Bahasan Sistem Persamaan Linear Dua Variabel Dan Teorema Pythagoras Kelas VIII SMP Citra Samata Kab. Gowa. Skripsi. Alauddin State Islamic University Makassar: Tidak diterbitkan.

Motlhabane, Abraham. (2017). Unpacking The South African Physicsexamination Questions According To Blooms' Revised Taxonomy. Journal of Baltic Science Education. Vol, 16 (6), 919-931.

Nurmadinah. (2017). Pengembangan Instrumen Tes Higher Order Thinking Skill (HOTS) Pokok Bahasan Operasi Hitung Bentuk Aljabar Serta Persamaan Dan Pertidaksamaan Linear Satu Variabel Kelas VII MTs Guppi Samata. Skripsi. Alauddin State Islamic University Makassar: Tidak diterbitkan.

OECD. (2019). PISA 2018 Result In Focus. Paris: OECD.

Rapih, S., \& Sutaryadi. (2018). Perspektif Guru Sekolah Dasar Terhadap High Order Thinking Skills (HOTS): Pemahaman, Penerapan, dan Hambatan. Jurnal Pendidikan Dasar dan Pembelajaran, Vol. 8 (1), 76-87.

Safitri, E., Sofiyan, Ramadhani D., \& Sukirno. (2019). Analisis Soal Ujian Matematika Semester Ganjil Pada SD Negeri 10 Langsa. Journal of Basic Education Studies, Vol 2 (1), 89-99.

Salmina, M., \& Adyansyah F. (2017). Analisis Kualitas Soal Ujian Matematika Semester Genap Kelas Xi Sma Inshafuddin Kota Banda Aceh. Numeracy Journal, Vol. 4 (1), $37-47$.

Sugiyono. (2017). Metode Pendidikan Pendekatan Kuantitatif, Kualitatif, dan R\&D. Bandung: Alfabeta.

Wulan, S., Jufrida, \& Pathoni, H. (2017). Pengembangan Modul Elektronik Berbasis 3D Pageflip Professional pada Materi Konsep Dasar Fisika Inti dan Struktur Inti Mata Kuliah Fisika Atom dan Inti. Jurnal EduFisika, Vol. 2 (1), 38-50. 